\title{
Playing with the Language: Investigating the Role of Communicative Games in an Arab Language Teaching System
}

\author{
Ali H. Al-Bulushi
}

Asst. Prof., Sultan Qaboos University, Sultanate of Oman, aha109@squ.edu.om

\section{Ali S. Al-Issa}

Assoc. Prof., Sultan Qaboos University, Sultanate of Oman, ali2465@squ.edu.om

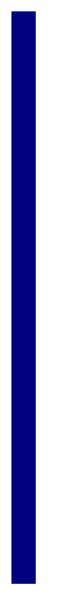

\begin{abstract}
Language learning games combine a number of linguistic, psychological and social elements that have been found to have considerable advantages and powerfully impact language learning and teaching. They are incorporated into language curricula to promote interactive engaging learning. This study investigates the role of games in the Omani ELT syllabus through conducting a thorough content analysis of Basic Education System English language textbooks across all grades as well as seeking the attitudes of teachers and students of three public schools representing the three teaching cycles in the educational system. A content analysis form and a questionnaire were used to collect data. Results showed that the Omani ELT syllabi endorsed a modest number of communicative games across grades, the majority of which focus on teaching vocabulary with a very timid focus on the language skills. Moreover, students hold highly positive attitudes about the role of games in improving their language whereas teachers have moderately positive attitudes about their role. Implications of these results on the language learning and teaching context are outlined.
\end{abstract}

Key Words: language learning games, teachers' attitudes, learners' attitudes, interactive learning, learning

\section{INTRODUCTION}

English language is the only official foreign language in the Sultanate of Oman and people use it for multiple significant purposes. The government has invested heavily in teaching English over the past four decades or so. Such investment took the shape of writing new textbooks, incorporating sophisticated and advanced educational technology and training teachers to handle Communicative Language Teaching (CLT)based classes (Al-Issa \& Al-Bulushi, 2011). However, English language teaching (ELT) in Oman has been described as dull and boring due to the largely traditional approaches implemented by the teachers (Al-Issa \& Al-Bulushi, 2011), which have not only affected

Citation: Al-Bulushi, A. H. \& Al-Issa, A. S. (2017). Playing with the Language: Investigating the Role of Communicative Games in an Arab Language Teaching System. International Journal of Instruction, 10(2), 179-198. https://doi.org/10.12973/iji.2017.10212a 
the students' language acquisitions and proficiency, but also negatively influenced their motivation and attitudes about the nature and importance of learning English.

Furthermore, the current national syllabus - English For Me (EFM), generally meets the needs and interests of the students in terms of the content and design and teaching of the different skills through a wide array of authentic and communicative tasks and activities (Al-Issa \& Al-Bulushi, 2011). However, research investigating students' attitudes about the Basic Education System (BES) that enforced EFM in public schools and compared it to the previous old education system found no significant difference in relation to the teaching activities and curriculum characteristics partially due to implementation shortcomings (Al-Issa \& Al-Bulushi, 2011). An important element of such tasks and activities is games. Games combine a number of linguistic, psychological and social elements that have been found to have considerable advantages and powerfully impact foreign language learning and teaching.

Arguing for the benefits of communicative games in language learning is similar to arguing for the usefulness of technology as it is only the implementation that would make the difference (Godwin-Jones, 2014). The set of variables playing a role in making gaming useful to the language learner either with the teacher's support in the classroom or at their leisure outside are endless and complex. English as a Foreign Language (EFL) learners respond differently to language learning games but it remains the teacher's role to create opportunities where introduction of communicative games would be useful to learners and encourage the development of their language.

With the proliferation of games and the growing interest of learners in playing them in their leisure time, it becomes paramount for educationalists to consider how they are presented in the language textbooks taught and tease how teachers and learners perceive their usefulness in their daily pedagogical interaction. This study, therefore, attempts to investigate the role of games in the Omani Basic Education System (BES) ELT syllabi through seeking the attitudes of teachers and students of public schools as well as conducting a content analysis of the current 1-12 BES English Language syllabi to see the representation of games within the whole set. A survey of the literature has shown that there is a need for such a study to complement the different theoretically discussed publications so far. This study, to the best knowledge of the authors, is the first of its kind to collect data quantitatively from the aforementioned sources about this topic.

\section{GAMES IN COMMUNICATIVE LANGUAGE TEACHING}

CLT arouse in response to traditional methods of language teaching that primarily focused on structural, notional, functional, or audio-visual learning. One of the goals of this approach is to involve language learners in task-based communicative interactions that would incrementally and incidentally help them become more communicatively competent and effectively use the language forms in real meaningful communicative situations in real life (Littlewood, 1981; Richards and Rodgers, 2001).

In order to develop learner's communicative competence, language learners in CLT are expectedly exposed to comprehensible input in the target language and encouraged to practically use the language for communicative purposes. The comprehensible input 
could be previously planned in several stress-free enjoyable language tasks such as games, role-plays, songs, stories, and interactive information-gap. Games, when executed properly in language classrooms, could particularly help to host language forms meaningfully and get the learners to learn or revise them that could help their language development. The success of planning and implementation of such language games largely depend on how teachers perceive their importance and contributions to the language development of their learners (Wang, 2010). Thus, it becomes vital to explore to what extend language teachers believe in the role of communicative games in doing so.

EFM, according to the Ministry of Education, was designed around communicative and skills-based methodology, which is expected to encourage learners to participate and interact collaboratively in a more learner-centered stress-free classroom (Ministry of Education, 1999, p. 11). It introduces language through appealing topics and tasks that target the four language skills together with grammar and vocabulary. Several learning techniques are also incorporated within the CLT-driven curriculum, which creates an appropriate room for educational games to be utilized in. In order to enhance students' fluency, Hadfield (1999) suggests techniques like guessing, information gap, matching, searching, collecting, exchanging, arranging, combining, puzzles, board games, card games, and role-playing. All of these techniques lend themselves well for being designed in game-forms given the teachers have the right attitude, time and resources to do that. However, English language teachers tend to teach towards tests (Al-Issa \& AlBulushi, 2011) rather than to improve the communicative competence of learners despite their knowledge and training to utilize CLT in teaching. Therefore, language learners tend to face many challenges when communicating in real-life situations, partially due to the minimal exposure to communicative authentic tasks that learners are exposed to in their classrooms including games.

\section{PLACE OF GAMES IN ELT}

Different writers have written about different aspects of games in education in general and in the ELT classroom in particular. Sahhusyeinoglu (2007) describes educational games in general as important for developing critical thinking skills, regardless of the age and stage they are used at. As far as ELT games are concerned, there is an abundance of research arguing for the positive effects of using games in teaching the language. For instance, Benavides (2009) writes that 'games provide contexts for playing, reasons for playing and routines for playing' (p. 7). Youxin (2010) describes games as refreshing in a boring and dull teacher-fronted, textbook-dominated and examgoverned context, like the Omani context, for instance. Ersoz (2000) considers games as good ice-breakers from usual routines of a traditional English language class.

Youxin (2010) considers ELT games as equally helpful and important for teachers and students. Games help teachers alter their techniques, styles, and approaches and make them more geared towards learner-centeredness. They help to promote language acquisition through lowering students' anxiety and creating an enjoyable learning atmosphere in the foreign language classroom (Benavides, 2009; Larcabal, 1992; Lee, 1979; Muhanna, 2012; Nguyen and Khuat, 2003; Youxin, 2010). Games further help the 
introduction and retaining of new concepts and lexical and structural aspects (Ajibade and Ndububa, 2008; Hadfield, 1999; Lengeling and Malarcher, 1997; Uberman, 1998). The same authors describe ELT games as enhancing learners' cognitive and affective development and improving class dynamics. Several researchers consider games as a significant source of improving students' language skills and linguistics proficiency through providing students with opportunities to use English naturally, communicatively, meaningfully and spontaneously that can have positive implications for their language use outside the classroom (Benavides, 2009; Deesri, 2002; Hadfield, 1999; Kim, 1995; Larcabal, 1992; Lee, 1979; Wright, Betteridge, and Buckby, 1984).Escudeiro and Carvalho (2013) agree that games develop students' language. They write that when using games, students learn from the mistakes they make. In her study, Muhanna (2012), suggests that vocabulary games are used to review language lessons to improve learners' communicative competence. Part of this communicative competence is that learners would be able to use the language in authentic realistic situations when playing games in L2 either individually or with their peers. Shameem and Makhan (2001) claim that language activities, including games, allow students to transform the strategies they use in realistic situations.

Ajibade and Ndububa (2008) and Benavides (2009) acknowledge the role of games as boosting learners' confidence and raising their interest, participation, and involvement, which can reflect positively on their feelings towards English. Ajibade and Ndububa (2008), Deesri (2002) and Wright et al. (1984) consider games as a powerful tool for enhancing students' motivation and interest in learning English through, what Nguyen and Khuat (2003) and Ajibade and Ndububa (2008) consider, the competitive environment they help create inside the classroom. Richard-Amato (1988) argues that students enjoy participating in language games because they want to try to win the games. Wright et al. (1984) stress the centrality of amusement and challenge in an ELT game. Moreover, ELT games, according to Ajibade and Ndububa (2008), Ersoz (2000) and Escudeiro and Carvalho (2013), can help engage students in cooperative and team learning. Escudeiro and Carvalho (2013) state that games enable students to learn by doing, in an engaging environment and that games improve teamwork, social skills, leadership, and collaboration. In this sense, Shameem and Makhan (2001) claim that students will develop interpersonal communication skills and fluency through the use of activities (used interchangeably with games). This is particularly important in a mixedability context like Oman's.

ELT games can thus be classified into 'competitive' and 'cooperative' (Hadfield, 1999). In the former category students try to reach the goal of the game, which is usually linguistic, while in the latter category, students work towards reaching a common goal through cooperating with their partners and team members in a potentially '. . joyful, enthusiastic and successful learning' (Ajibade and Ndububa, 2008, p. 31).

Hadfield (1999) further uses 'linguistic' and 'communicative' classifications of games to refer to accuracy-focused in the former, while in the latter referring to fluency-focused. Ajibade and Ndububa (2008) explain how games form an integral part of the Communicative Language Teaching (CLT) approach. 
Games are task-based and have a purpose beyond the production of correct speech. They are an example of the most preferable communicative activities: this type of activity highlights not only the competence, but also the performance of the learner. Thus, it is an indispensable part of any English lesson because it reinforces the form-discourse match (p. 31).

Furthermore, games, according to De Jager (2009), can be divided into 'mental' and 'physical', ranging from active to quiet, and from basic to advanced. The former category keeps learners mainly focused on speaking and producing the target language. On the other hand, the latter category keeps learners concentrated on their own answers. Language learning physical games are more pertinent to young learners who more senseoriented in learning whereas mental games are more age-appropriate for older learners.

Carrier (1990) acknowledges that ELT teachers have a wide array of games to choose from, to help them achieve their aims and objectives. Learners' language proficiency, their characteristics, learning styles and the feasibility of the game are claimed to be four main factors that can influence the effectiveness of an ELT game and determine its choice (Deesri, 2002). Brumfit (1991), Byrne (1997) and Kopechy (2009) draw teachers' attention to keep in mind certain parameters when using a game. These are the harmony between the focus of the game and the aims and objectives of the lesson, establishment of participation rules, organization of the game, and the starting and stopping time. Despite this caveat, it is not clear, at least empirically, if teachers are using such criteria for selection of games or resorting to them only to break the ice in the classroom.

However, Vernon (2008) warns that games may not work all the time in an ELT class and teachers find it hard to incorporate them into the class due to a number of reasons attributed to problems with lack of time or new ideas, teacher-proof materials, students' different learning styles and preferences, and classroom management issues like mixedability classes and lack of attention or cooperation on the part of the students. In line with Vernon's study, Lawrence and Lawrence (2013) investigated the attitudes of student teachers about using grammar games in the classroom and found that the majority of them have a favorable attitude towards using these games at the secondary level. Although one would expect educational games to work better with younger learners, studies like the latter one suggest that the context where the study is applied, the attitudes of participants, and the type of games investigated play important roles in determining how they are perceived and used.

\section{RATIONALE}

The English language curricula consist of a number of skill-based activities and tasks categorized thematically and sequenced according to progressively structured levels. Communicative games have been infused in the ELT curricula variably across all grades. Language teachers are expected to teach them along with the other content but without any clear rationale about their role in improving the learners' language neither how they are cohesively related to the other language skills of the syllabi. Despite the importance of communicative games in students' language learning, no previous research has accounted for their representation in a whole set of nationally used ELT 
syllabi. In addition, it is important to find how teachers and students perceive their role in teaching and learning via communicative games as their viewpoints influence how they approach them when used in the classroom in terms of the time allocated for teaching them, the resources used to do that, and the relationship between them and the teaching and learning of other language skills. Moreover, there is a paucity of research in this area to help us understand the representation of games in formal language textbooks and the contribution of the teachers and students' attitude about using games in the EFL classroom especially within different instructional levels in public education like the context of this study.

\section{METHOD}

\section{Research questions}

This study seeks to answer the following questions:

1. What are the attitudes of the students about the role of communicative games in the Omani Basic-Education ELT system?

2. What are the attitudes of the teachers about the role of communicative games in the Omani Basic-Education ELT system?

3. Are there any statistically significant differences between the attitudes of teachers and students regarding the use of communicative games in ELT classrooms?

4. To what extent are English language communicative games presented in the Basic Education ELT system?

\section{Participants}

The participants in the study are of two types: English language teachers and learners. Twenty-nine Omani and non-Omani teachers with various teaching experiences in teaching in the BES cycle 1 (grades 1-4), cycle 2 (grades 5-10), and post-basic education (grades11and12) were involved in the study. In addition, the attitudes of 23 students from 3 schools from the 3 stages of the system were sought (see the Table 1). Young learners in cycle 1 are males and females and taught only by female teachers according to the policy of the Ministry of Education. On the other hand, cycle 2 and post-basic stages are gender-separated and taught by teachers from the same gender of students. All teachers teach using the same official English language textbooks written by the Ministry.

Table 1

Distribution of participants across schools and cycles

\begin{tabular}{cccccc}
\hline School & Teachers & C1 ss & C2 ss & Post-basic ss & Ss total \\
\hline A & 7 & 8 & 6 & 0 & 14 \\
\hline B & 14 & 0 & 3 & 0 & 3 \\
\hline C & 8 & 0 & 0 & 6 & 6 \\
\hline Total & 29 & 8 & 9 & 6 & 23 \\
\hline
\end{tabular}

Instruments

Two questionnaires mirroring each other in terms of statements were prepared to seek the attitudes of each type of participants. The statements primarily stemmed from the literature and the researchers' familiarity with the English language textbooks taught at public schools. A survey of the textbooks helped in creating the instruments. The 
validity and reliability of both questionnaires were maintained prior to administration. The former was established via a jury of eight experts in the area who gave constructive comments that improved the statements of the questionnaires. The latter was established by calculating Cronbach Alpha of the teachers' questionnaire and the learners' questionnaire, which were 0.929 and 0.932 respectively indicating highly reliable levels.

The teachers' questionnaire includes 31 items, reflecting the role of games in the Omani ELT educational system. The items of this questionnaire tackled several themes divided as follows: language learning games in the classroom (theme 1), designing languagebased activities (theme 2), the organization of games in the classroom (theme 3), and syllabus and textbook games (theme 4).

The students' questionnaire includes 28 items, also covering different themes. These themes include games and language skills (theme 1), preferred types of games (theme 2 ), playing games and language learning (theme 3), and playing games cooperatively (theme 4).

A content analysis form was created to analyze the English language learning games designed in the ELT BES system syllabi. It was created based on the literature and the researcher's knowledge about the Omani English language syllabi and context. The form was sent to a jury for validation prior to implementation. Some of the modifications suggested required adding extra descriptors and classifying games according to genre which were incorporated in the final version.

\section{Procedures}

After randomly selecting the schools, the questionnaires were sent to the subjects and asked to read the instructions carefully before attempting to record their answers. Before administering the questionnaire to the students, a decision was taken to translate their version into Arabic in order to avoid any confusion or misunderstanding of the statements, especially to the lower grades. The questionnaire instructions and statements were carefully read to Cycle 1 students (grade 1-4) and were asked to indicate their responses using smilies rather than words or ticks. Cycle 2 and post-basic learners did not have issues in responding to the translated version of the questionnaire.

All English language textbooks taught to all grades (1-12) were collected. Before embarking on the content analysis, the two researchers deliberated on the form to established a common understanding of the descriptors after its validation. Three grade level textbooks (grade 2,6 \&11) were piloted in using the content analysis form. An acceptable level of inter-rater reliability $(0.82)$ was established between the evaluators. Each research took 6 grades' syllabi to evaluate using the form.

\section{FINDINGS}

Table 2 shows the results of the students' questionnaire. Students apparently agree with most of the statements with a grand mean of 4.12 on the 5-point Likert scale of the questionnaire. They clearly stated that they like learning English through English games with a mean 4.35 . When asking them about the language skills they like playing games when practicing, they indicated that they like playing games, which use more than one language skill (4.52). In fact, it is quite investable to play well-crafted language learning 
games without using several language skills. Oxford (2001) asserts that using integrated language instruction in the language classroom could be highly motivating for students from various age groups and backgrounds. This result provides a reason for the agreement with items $11,13,14,15,16$ and 18, with means of 4.39, 4.35, 4.09, 4.35, 4.48 and 4.22 respectively. Similar results are found in Deesri (2002); Hadfield (1990), Hatch (1998), Kim (1995); Larcabal (1992); Lee (1995) and Wright, Betteridge, and Buckby (1984), that games are important for improving students' language skills and linguistic proficiency. Infusing games in lessons would be challenging to teachers but striving to do that with language learning tasks that lend themselves to such modification would leave a favorable impression about learning the language.

Table 2

Means and SD of the students' attitudes towards using games to learn English

\begin{tabular}{|c|c|c|}
\hline Items & Mean & $S D$ \\
\hline My teacher plays games with me in the classroom. & 3.87 & 1.46 \\
\hline There is an adequate number of games in the textbook. & 3.83 & 1.07 \\
\hline 3. I like learning English through games. & 4.35 & .88 \\
\hline 4. $\quad$ I like playing games in groups. & 4.17 & 1.19 \\
\hline 5. I like playing games in pairs. & 4.17 & 1.11 \\
\hline 6. I like playing games in front of the class. & 4.35 & 1.07 \\
\hline 7. I prefer playing games on the computer. & 3.65 & 1.53 \\
\hline 8. I like playing chalk and board games. & 4.17 & 1.19 \\
\hline 9. $\quad$ I like playing card games. & 3.87 & 1.29 \\
\hline 10. I like it when the teacher is involved as a player in the game. & 4.00 & 1.31 \\
\hline 11. I like playing grammar games. & 4.39 & 1.12 \\
\hline 12. I like playing vocabulary games. & 3.87 & 1.46 \\
\hline 13. I like playing speaking games. & 4.35 & 1.15 \\
\hline 14. I like playing writing games. & 4.09 & 1.20 \\
\hline 15. I like playing listening games. & 4.35 & 1.03 \\
\hline 16. I like playing reading games. & 4.48 & .79 \\
\hline $\begin{array}{l}\text { 17. I like playing games which use more than one language skill (speaking, } \\
\text { writing, listening, or reading). }\end{array}$ & 4.52 & .79 \\
\hline 18. Playing games helps me improve my language. & 4.22 & .90 \\
\hline 19. Playing games in the classroom motivates me to learn. & 3.70 & 1.43 \\
\hline 20. Playing games strengthens my relationships with my classmates. & 4.00 & 1.38 \\
\hline 21. I like playing classroom games that involve mental challenge. & 3.91 & 1.44 \\
\hline 22. I use English only when I play games in the classroom. & 3.87 & .97 \\
\hline 23. I think in English when I play games in the classroom. & 3.87 & 1.06 \\
\hline $\begin{array}{l}\text { 24. I like playing classroom games with my friends and family members after } \\
\text { school. }\end{array}$ & 4.39 & .89 \\
\hline 25. I like playing games because I like to win. & 4.39 & .99 \\
\hline 26. Playing games gives me a chance to practice my English with my classmates. & 4.09 & 1.24 \\
\hline 27. I like playing classroom games that involve physical effort. & 4.09 & 1.31 \\
\hline 28. I prefer receiving the instructions of the games in English. & 4.26 & 1.42 \\
\hline $\begin{array}{c}\text { Total } \\
\end{array}$ & 4.12 & .71 \\
\hline
\end{tabular}

Students also indicated that they prefer receiving the instructions of the games in English with a mean of 4.26. One would expect that in order to get the instructions for playing the game correctly, they would be sought in L1. One reason behind this is 
possibly the students' realization or the teachers' inclination that students should be exposed as much as possible to language input when learning even through games. This result supports Youxin (2010) study, in which games help increase students' language acquisition.

The analysis also shows that the students agree with both playing games in groups and pairs (items 4 and 5), having the same mean 4.17. Although individual and class games could be useful, pair work and group work in designing games ensure that each and every learner has an optimum opportunity for practicing and using the language (Wright et al., 1984). Playing cooperatively in pairs and groups allows them to transfer this cooperation to outside the classroom, in a stress-free interaction. This supports the result of Ajibade and Ndububa (2008) and Ersoz (2000) that games help students engage in cooperative and team learning.

It is not surprising to note that students like playing classroom games with friends and family members even after school (item 24, mean=4.39). Nowadays, the electronic recourses that students can use to learn English outside the classroom are numerous such as hand-held devices or game consoles or even smartphones. This result is in line with another study conducted in the same context by (Al-Bulushi \& Al-Issa, 2012) who investigated the use of out-of-class strategies by Omani EFL learners to improve their language at school. They found that a considerable number of the participants considered games, which involve sophisticated audio/video technology, as a significant source of acquiring English. Moreover, students agree with item 25, 'I like playing games because I like to win', with a mean of 4.39. This agreement confirms RichardAmato (1996) argument of students participating in language games to try to win. It also shows that they like the competitive atmosphere that games create (Nguyen and Khuat, 2003; and Ajibade and Ndububa, 2008).

The lowest mean is 3.65 pertinent to playing games using computers. Although it indicates above-average mean, it should be stated that each public school has a computer lab within the learning resource center, which all schools' teachers could book and use in teaching some of their lessons. This suggests that the games that learners play and through which they may learn any language is primarily practiced outside the classroom. Hidden, unmonitored, and self-learning opportunities are inevitable and available to learners depending on their socioeconomic conditions and it is the teacher's task to create a stronger link between how language learning in the classroom can foster learning outside it and vice versa.

Therefore, in order to answer the first research question regarding the attitudes of the students about the role of games in the Omani Basic-Education ELT system, it could be stated that they hold a highly positive attitude with the grand mean of 4.17 as well as the above 3 mean in all the statements. Similar to Rahimi \& Hassani (2012) results, the positive attitudes revealed by students had positive attitude towards learning English as a foreign language. They provide an appropriate standpoint for teachers to seriously consider infusing games in teaching the different language skills. Motivating learners to learn is one of the major obstacles that teachers constantly face in the classroom and as 
Ajibade and Ndububa (2008) and Wright et al. (1984) highlighted that using games to foster their motivation could be a worthwhile instructional cause in itself.

On the other hand, the teachers were mostly neutral to the items in the questionnaire, albeit some interesting results were found. Teachers moderately tend to like using games to teach English as the grand mean is 3.71. Most of them agreed that they like playing games, particularly when teaching in the classrooms with a mean of 4.35 . This high mean is quite encouraging as it defies the stereotypical idea among some learners and parents that playing games might not be favored in teaching in public schools. It also reflects a level of creativity of the language teachers, which was deficient in some studies in the same context such as Al-Mahrooqi (2012).

Teachers also believed that playing games strengthens their relationships with their students', with a mean of 4.31. Playing games in the classroom did not only motivate students but according to the teachers, they also motivate them to teach (4.28). Playing games also adds fun and positive change to their lessons', with a mean of 4.28 and 4.24 respectively. Their agreement with these statements suggests positive attitudes towards using games in the classroom. Similar results were found by Larcabal, 1992; Lee, 1979; Nguyen and Khuat, 2003; Shultz, 1998; Youxin, 2010. These researchers also assert that games lower students' anxiety and create a relaxed atmosphere in the classroom.

Table 3

Means and SD of the teachers' attitudes towards using games to teach English

\begin{tabular}{|c|c|}
\hline Items & Mean SD \\
\hline 1. I like playing games with my students in the classroom & $4.35 \quad .86$ \\
\hline 2. There is an adequate number of games in the textbook & 2.521 .18 \\
\hline 3. I like teaching English through games & 4.17 \\
\hline 4. I find the time to include playing games in my lessons & $3.24 \quad 1.12$ \\
\hline 5. I consider games as an essential component in my lessons & 3.46 \\
\hline 6. I get my students to play all the games in the textbook & 3.00 \\
\hline 7. I modify the games suggested by the textbook when introducing them to my students & 3.66 \\
\hline 8. $\quad$ Playing games in the classroom motivates me to teach & 4.28 \\
\hline 9. I like organizing games in groups & 4.10 \\
\hline 10. I like organizing games in pairs & 3.64 \\
\hline 11. I prefer organizing games that my students can play on the computer & 3.521 .15 \\
\hline 12. I prefer organizing chalk and board games & $3.46 \quad .96$ \\
\hline 13. I prefer organizing card games & $3.69 \quad .89$ \\
\hline 14. I like being involved as a player in the game & $3.45 \quad 1.15$ \\
\hline 15. I prefer selecting / designing grammar games & $4.10 \quad .77$ \\
\hline 16. I prefer selecting / designing vocabulary games & $3.97 \quad 1.12$ \\
\hline 17. I prefer selecting / designing games which focus on receptive skills & $3.59 \quad .82$ \\
\hline 18. I prefer selecting / designing games which focus on productive skills & 3.62 \\
\hline 19. I prefer organizing games which integrate more than one language skill & 4.03 \\
\hline 20. Playing games adds fun and positive change to my lessons & $4.24 \quad 1.24$ \\
\hline 21. I reward the winning students after competitive games & $3.86 \quad 1.13$ \\
\hline 22. Playing games strengthens my relationships with my students & $4.31 \quad 1.14$ \\
\hline 23. I instruct my students to use English only when playing games in the classroom & $3.90 \quad 1.26$ \\
\hline 24. I only use English when instructing my students to play games & $3.45 \quad 1.35$ \\
\hline $\begin{array}{l}\text { 25. I keep the level of my students in mind when selecting/ designing games to play in the } \\
\text { classroom }\end{array}$ & $4.14 \quad 1.22$ \\
\hline
\end{tabular}




\begin{tabular}{|c|c|}
\hline 26. I like selecting/designing classroom games that involve physical effort for my students & 3.66 \\
\hline 27. I like selecting/designing classroom games that involve mental challenge for my students & 4.00 \\
\hline 28. I design my own games for my learners & 3.61 \\
\hline 29. I only play games with my students which are presented in the syllabus & $2.59 \quad 1.18$ \\
\hline 30. I design games that target my students' language weaknesses & 3.83 \\
\hline 31. I involve my students in making a decision about the games to play in the classroom & 3.66 \\
\hline Total & 3.71 \\
\hline
\end{tabular}

The results also suggest that teachers do not find an adequate number of games in the textbook, (mean =2.52), which explains why they do not restrict themselves to the games presented in the textbook (mean=2.59). This suggests that teachers are aware of the insufficiency of games in the textbook. The mean 2.59 is quite moderate to suggest that teachers seek supplementary materials to fill the insufficiency gap. This is attributed to the strict abidance of teachers to the textbooks they teach as some studies indicated such as (Al-Issa \& Al-Bulushi, 2011). Wood (2001) investigated the use of learning games as a learning tool and found that game-like formats could be more effective at capturing learners' attention than conventional media such as textbooks. Having said that, there is a clear contradiction between the insufficiency mean of teachers (2.52) and its students' counterpart (3.83) in table 2. In other words, while the teachers find the games are insufficient in number, their students find them sufficient which could be attributed to the learners' lack of differentiation if the games are part of the textbook or supplemented by their teachers.

Teaching English through using games does not ensure effective learning or increase students' motivation without an intentional plan of using them to meet specific instructional objectives of the language learning course. For instance, a teacher could play snakes and ladders and have fun with his students but without relating the game to certain language objectives (e.g. distinguishing between imperatives and modal verbs) and giving students feedback throughout the teaching process, mere fun would override learning through it. Wright et al. (1984) assert that teachers should facilitate learning while the game is being played, correcting the language only if necessary.

Thus, in order to answer the second research question regarding the attitudes of the teachers about the role of games in the Omani Basic-Education ELT system, it could be stated that they hold a moderately positive attitude with the grand mean of 3.71 . Teachers believe that games could play a role in improving the students' language and that they do use them in the classroom. These results were echoed by Rahimi \& Hassani (2012) in their study with Iranian EFL learners and teachers. However, given the paucity of games in the textbook, they indicated that the teachers in the current study do not strive to bring them from external sources.

As far as the third research question that asks about any significant differences between the attitudes of teachers and students regarding the use of games in ELT classrooms is concerned, the grand means of teachers and students were compared using a t-test. The result indicates that there is a statistically significant difference between the two $(p=0.027<0.05)$ in favour of students. 
Table 4

Means difference between teachers and students

\begin{tabular}{cccccc}
\hline Type & $N$ & Mean & SD & $T$ & $P$ \\
\hline Students & 23 & 4.12 & .71 & \multirow{2}{*}{2.28} & \multirow{2}{*}{027} \\
\hline Teachers & 29 & 3.71 & .57 & & \\
\hline
\end{tabular}

The significant difference between both groups, as delineated in Table 4 above, suggests that students are more inclined to possess positive attitudes about using games in learning English in the classroom than teachers. This tendency if realized by teachers and syllabus designers could be incorporated in the textbooks and the classrooms to foster students learning through games.

The content analysis of all BES syllabi indicated that English language learning games variably exist in the BES syllabi with 6 games in grade 2 and grade 5 separately compared to no games in grades 4 and 8 . Interestingly, the number of games are almost the same in cycle 1 grades (1-4) and cycle 2 (5-10) despite that the latter has 6 grades compared to only 4 grades in the former. Figure 1 below illustrates these numbers.

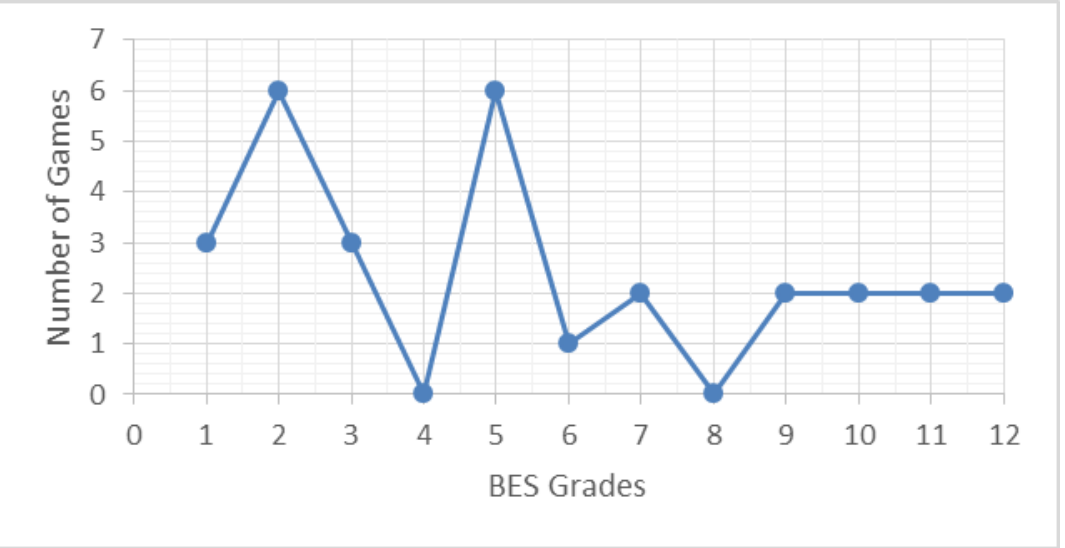

Figure 1

Number of ELL game in the BES Syllabi

Although it is not surprising to see more games in the syllabi of young learners in cycle 1 , having no games at all in grade 4 and grade 8 seems to leave teachers to their own creativity to bring games to the classrooms. On the contrary, the highest grades in the Omani BES (post-basic) hosts the least number of games. All the games in this cycle primarily focus on vocabulary and less on listening and speaking with crosswords as the dominant game type. This reinforces De Jager (2009) typology, as mental games are pertinent to older language learners as opposed to physical games for young learners.

While the students think that there is adequate number of games in the textbooks (mean=3.83), the teachers have the contrary views that they are insufficient $($ mean=2.52). The content analysis of communicative games in the BES textbook corroborated the teacher's views and showed scarcity of games across the grades. This 
could be attributed to the students who do not have the specialized background for judging the number of games in the textbooks and may have based their views on how the teachers presented language learning tasks and activities. This result could also be due to the teachers' conventional reliance on textbooks, test-based teaching, and focusing on finishing the materials either with the specified games or without.

The number of games and their distribution across the grades would be more useful to be looked at in relation to the language learning skills and focus (i.e. grammar and vocabulary) which are demonstrated in the Figure 2 below.

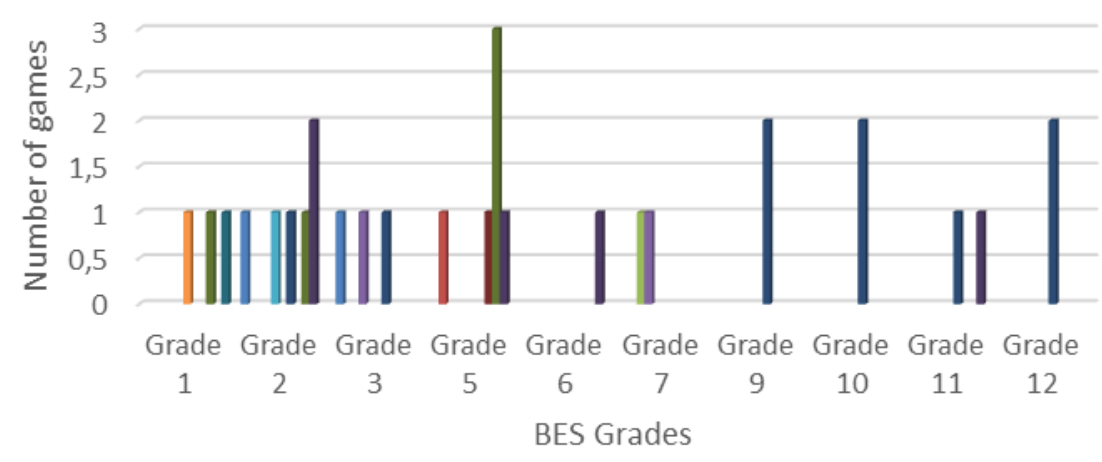

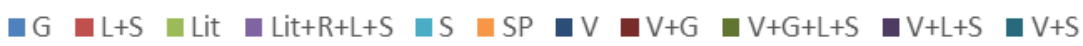

Figure 2

Number of games per language skills/focus across BES grades

As figure 2 shows, the common language skill/focus across all grades is vocabulary scoring 9 games exclusively across all grades and 12 other games targeting vocabulary with at least another language skills/focus such as listening, speaking or grammar. Interestingly the highest grades starting from grade 9 onwards have vocabulary games primarily. One would expected more challenging games teasing learners' minds and developing their mental abilities would be encouraged there but all the non-vocabulary games occurred in cycle 1 and 2 grades.

\section{CONCLUSION}

This study has sought to find students and teachers' attitudes about the role of using games in the EFL classroom as well as to seek the representation of communicative games in the BES textbooks. The students hold positive attitudes about using games arguing that games could help them in improving their language inside and outside the classroom. The teachers held a slightly less positive attitude in general about using games in the classroom. The less exposure to games in the EFL curriculum they are teaching was the main reason behind their reticent stance. This was corroborated by the content analysis that found only 29 games only across all the grades in the public basic education system textbook which primarily focus on lexical games. In order to use 
games effectively in the EFL classroom, teachers and students should provide the necessary positive monitoring, control, and environment for learning to take place (Macedonia, 2005).

Playing objective-driven communicative language games in the classroom might be perceived as peripheral by some teachers but if planned well within the curriculum it could at least improve students' attitudes towards learning the language as indicated by students in this study. Further studies are needed to see if what teachers and students perceive about the use of language games are really practiced in the EFL classroom. Coverage and classification of games as presented in the curriculum taught could be suggested in a content-analysis descriptive study.

Finally, the BES highlighted the importance of instructional technology by incorporating it in the English language curriculum in order to enhance learning the language skills. Learners are encouraged to use it in the school and outside it to practice the language. As technology plays an important role in gaming with younger generations, it is worthwhile to investigate how educational games practiced in the class and extended outside it could improve learners' language skills.

Some limitations of this study must be highlighted. First, the data are geographically limited because it was collected at few schools in Muscat. Second, the content analysis only covered English language class books that language teachers and students use in the classroom. The study excluded other textbooks from the analysis (i.e. teacher's guide and workbook) as they are used separately by either teachers or students outside the classroom for primarily planning or practice. Therefore, readers should interpret the study's results with caution as they may not be generalizable to other settings. Other researchers could collect data from public or possibly private schools or higher education institutions, which would better represent the population.

\section{REFERENCES}

Ajibade, Y. \& Ndububa, K. (2008). Effects of word games, culturally relevant songs, and stories on students' motivation in a Nigerian English language class. TESL Canada Journal, 25.

Al-Bulushi, A., \& Al-Issa, A. (2012). Investigating out-of-Class English Language Learning Strategies by Omani Learners. In R. Al-Mahrooqi \& A. Mahmoud (Eds.), Issues in Teaching EFL in the Arab World. Muscat: Sultan Qaboos University Press.

Al-Issa, A. S., \& Al-Bulushi, A. H. (2011). English Language Teaching Reform in Sultanate of Oman: The Case of Theory and Practice Disparity. Educational Research for Policy and Practice, 11(2), 141-176.

Al-Mahrooqi, R. (2012). A student perspective on low English proficiency in Oman. International Education Studies, 5, 263-271.

Benavides, E. A. 2009. Interacting in English through games. Profile. 
Brumfit, C. (1991). The communicative approach to language Teaching. Oxford, Oxford University Press.

Byrne, D. (1997). Teaching oral English. England, Addison Wesley Longman Limited.

Carrier, M. (1990). Take 5 games and activities for the language learner. Edinburgh, Nelson's Company.

De Jager, M. (2009). BabyGym. Brain and body gym for babies. Welgemoed, South Africa, Wetz Press.

Deesri, A. (2002). Games in the ESL and EFL classes. The Internet TESL Journal, 8.

Ersoz, A. (2000). Six games for the EFL/ESL classroom. The Internet TESL Journal, 6.

Escudeiro, P. \& Vaz De Carvalho, C. (2013). Game-based language learning. International Journal of Information and Education Technology, 3, 643-647.

Godwin-Jones, R. (2014). Games in language learning: Opportunities and challenges. Language Learning \& Technology, 18(2), 9-19.

Hadfield, J. (1999). Intermediate vocabulary games. Harlow, Essex, Longman.

Kim, L. 1995. Creative games for the language class. English Teaching Forum, 33, 3536.

Kopechy, A. (2009). Using games to motivate your adult ESL students [Online]. Available:

http://www.eslfocus.com/articles/using_games_to_motivate_your_adult_esl_students400.html [Accessed 12 August 2015].

Larcabal, R. (1992). The role of games in language acquisition. English Teaching Forum, 30, 28-29.

Lawrence, A. J. \& Lawrence, A. S. 2013. Attitude of student teachers towards using grammar games for teaching English. International Journal on New Trends in Education and their Implications, 4, 65-72.

Lee, W. (1979). Language teaching games and contests. Oxford, Oxford University Press.

Lengeling, M. \& Malarcher, C. (1997). Index cards: A natural resource for teachers. ET Forum, 35-42.

Littlewood, W., (1981). Communicative language teaching: An introduction, Cambridge: Cambridge University Press.

Richards, J. C. and Rodgers, T. S., (2001) Approaches and Methods in Language Teaching, Cambridge: Cambridge University Press.

Macedonia, M. (2005). Games and foreign language teaching. Support for Learning, 20, 135-140. 
Ministry of Education (1999). English language curriculum framework. Muscat, Oman, Ministry of Education.

Muhanna, W. (2012). Using online games for teaching english vocabulary for jordanian students learning English as a foreign language. Journal of College Teaching \& Learning (Online), 9, 235.

Nguyen, T. \& Khuat, T. (2003). Learning vocabulary through games: The effectiveness of learning vocabulary through games. Asian EFL Journal, 5.

Oxford, R. (2001). Integrated skills in the ESL/EFL classroom. ERIC Digest.

Rahimi, M., \& Hassani, M. (2012). Attitude towards EFL textbooks as a predictor of attitude towards learning English as a foreign language. Procedia - Social and Behavioral Sciences, 31, 66-72.

Richard-Amato, P. (1988). Making it happen: Interaction in the second language classroom: From theory to practice. New York, Longman.

Sahhusyeinoglu, D. (2007). Educational games for developing critical thinking skills: Pre-service English language teachers' Views. ERIC, 32, 266-273.

Shameem, N. \& Makhan, T. (2001). New ways in using communicative games in language teaching. The Modern Language Journal, 85, 148-149.

Uberman, A. (1998). The use of games for vocabulary presentation and revision. English Teaching Forum, 36, 20-27.

Vernon, S. (2008). How to Effectively Use Games in the Preschool and Elementary ESL Classes [Online]. Available: http://eslarticle.com/pub/english-language-teaching-elt/83how-to-effectively-use-games-in-the-preschool-and-elementary-esl-classes.html [Accessed].

Wang, Y.H. (2010). Using communicative language games in teaching and learning English in Taiwanese primary schools. Journal of Engineering Technology and Education, 7(1), 126-142.

Wood, J. (2001). Can software support children's vocabulary development? Language Learning \& Technology, 5, 166-201.

Wright, A., Betteridge, D. \& Buckby, M. (1984). Games for language learning. Cambridge, Cambridge University Press.

Youxin, N. (2010). Using games to motivate chinese college students' interest in learning English. University of Wisconsin-Platteville. 


\section{APPENDIX A \\ Teachers' Questionnaire}

Dear English Language Teacher,

My colleague and I are conducting a study aiming at investigating the role of games in the Omani ELT educational system textbooks. We would appreciate it a lot if you could kindly read each of the statements below and indicate to what extent you agree with it by ticking the box opposite it. We would like to assure you that the data will only be used for the sake of this research and it will be treated with confidentiality.

Thank you for your cooperation

School:

Qualification:

Graduated from:

Years of experience:

\begin{tabular}{l|l|l|l|l|l|l|l|l|} 
SD: Strongly Disagree & D: Disagree & N: & Neutral \\
A: Agree & SA: Strongly Agree & & \\
\hline
\end{tabular}

\begin{tabular}{|c|c|c|c|c|c|}
\hline Statements & $S D$ & $\bar{D}$ & $N$ & $A$ & $S A$ \\
\hline I like playing games with my students in the classroom & & & & & \\
\hline There is an adequate number of games in the textbook & & & & & \\
\hline I like teaching English through games & & & & & \\
\hline I find the time to include playing games in my lessons & & & & & \\
\hline I consider games as an essential component in my lessons & & & & & \\
\hline I get my students to play all the games in the textbook. & & & & & \\
\hline I modify the games suggested by the textbook when introducing them to my students & & & & & \\
\hline Playing games in the classroom motivates me to teach & & & & & \\
\hline I like organizing games in groups & & & & & \\
\hline 10. I like organizing games in pairs & & & & & \\
\hline 11. I prefer organizing games that my students can play on the computer & & & & & \\
\hline 12. I prefer organizing chalk and board games & & & & & \\
\hline 13. I prefer organizing card games. & & & & & \\
\hline 14. I like being involved as a player in the game & & & & & \\
\hline 15. I prefer selecting / designing grammar games & & & & & \\
\hline 16. I prefer selecting / designing vocabulary games & & & & & \\
\hline 17. I prefer selecting / designing games which focus on receptive skills & & & & & \\
\hline 18. I prefer selecting / designing games which focus on productive skills & & & & & \\
\hline 19. I prefer organizing games which integrate more than one language skill & & & & & \\
\hline 20. Playing games adds fun and positive change to my lessons & & & & & \\
\hline 21. I reward the winning students after competitive games & & & & & \\
\hline 22. $\quad$ Playing games strengthens my relationships with my students & & & & & \\
\hline 23. I instruct my students to use English only when playing games in the classroom & & & & & \\
\hline 24. I only use English when instructing my students to play games & & & & & \\
\hline $\begin{array}{l}\text { 25. I keep the level of my students in mind when selecting/ designing games to play in the } \\
\text { classroom }\end{array}$ & & & & & \\
\hline 26. I like selecting/designing classroom games that involve physical effort for my students. & & & & & \\
\hline 27. I like selecting/designing classroom games that involve mental challenge for my students. & & & & & \\
\hline 28. I design my own games for my learners & & & & & \\
\hline 29. I only play games with my students which are presented in the syllabus & & & & & \\
\hline 30. I design games that target my students' language weaknesses & & & & & \\
\hline 31. I involve my students in making a decision about the games to play in the classroom. & & & & & \\
\hline
\end{tabular}

International Journal of Instruction, April $2017 \bullet$ Vol.10, No.2 


\section{Turkish Abstract \\ Dil ile Oynamak: Arap Dil Öğretim Sistemindeki İletişim Oyunlarının Rolünü İncelemek}

Sözel, psikolojik ve sosyal elementleri bir araya getiren dil öğrenme oyunları, dil öğreniminde ve öğretiminde dikkate değer ölçüde avantajlı bulunmaktadır. Bu oyunlar dil müfredatına, etkileșimli dil öğrenmeye katkıda bulunarak dahil olurlar. Bu çalışma, 3 devlet okulundaki 3 farklı öğretim döngüsüne sahip eğitim sistemlerindeki öğrenciler ve öğretmenlerin davranışlarını araştırmanın yanında Temel İngilizce Eğitim Sistemi ders kitabınıdaki Omani ELT programındaki oyunların rolünü araştırmaya yöneli bir bir içerik analizidir. İçerik analizi form ve anketleden elde edilen verilerle yapılmıştır. Sonuçlar, Omani ELT programının çeşitli seviyelerdeki iletişim oyunları, dil becerilerine odaklanmadan hazırlanmış yalın kelime öğretimi etkinlikleri ile uygun olduğunu göstermiştir. Buna ilave olarak, öğrencilerin dillerini geliştirmede oyunların etkisine karşı olumlu bir tutum içinde oldukları; öğretmenlerinin de bu durumla ilgili olumlu düşündükleri gözlenmiştir.

Anahtar Kelimeler: dil öğrenme oyunları, öğretmen tutumları, öğrenci tutumları, etkileşimli öğrenme

\section{French Abstract \\ Jeu avec la Langue : Examen du Rôle de Jeux Communicatifs dans un Système d'Enseignement des langues arabe}

Les jeux d'apprentissage des langues combinent un certain nombre d'éléments linguistiques, psychologiques et sociaux qui ont été trouvés pour avoir des avantages considérables et ont puissamment un impact sur l'apprentissage des langues et l'enseignement. Ils sont incorporés dans des programmes d'études de langue pour promouvoir l'apprentissage d'engagement interactif. Cette étude examine le rôle de jeux dans le programme ELT omanais par la conduite d'une analyse de contenu minutieuse de manuels de langue anglaise de Système de Formation initiale à travers toutes les catégories aussi bien que la recherche des attitudes de professeurs et les étudiants de trois écoles publiques représentant les trois cycles enseignants dans le système éducatif. Une forme(Un formulaire) d'analyse de contenu et un questionnaire ont été utilisés pour rassembler(prendre) des données. Les résultats ont montré qu'ELT omanais syllabi a approuvé un nombre(numéro) modeste de jeux communicatifs à travers des catégories, la majorité de lequel l'accent du vocabulaire enseignant avec un accent très timide des compétences linguistiques. De plus, les étudiants tiennent des attitudes fortement positives du rôle de jeux dans l'amélioration de leur langue tandis que les professeurs ont des attitudes modérément positives de leur rôle.

Mots Clés: jeux d'apprentissage des langues, les attitudes de professeurs, les attitudes d'apprenants, apprentissage interactif 


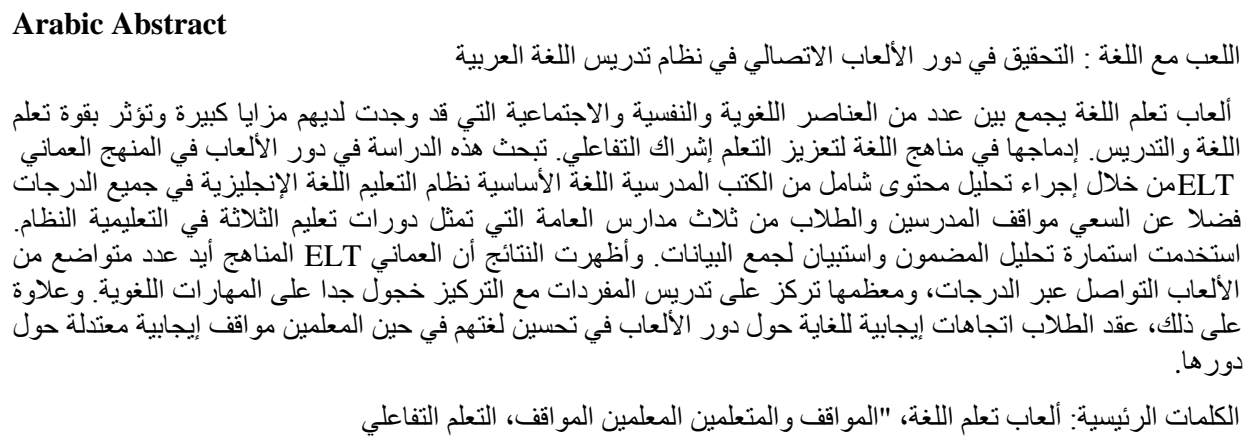

\section{German Abstract \\ Spielen mit der Sprache: Untersuchung der Rolle der kommunikativen Spiele in einem arabischen Sprachlehrsystem}

Sprachlernspiele kombinieren eine Reihe von sprachlichen, psychologischen und sozialen Elementen, von denen festgestellt wurde, dass sie erhebliche Vorteile haben und das Sprachlernen und Lehren stark beeinflussen. Sie sind in Sprachcurricula integriert, um das interaktive Engagement zu fördern. Diese Studie untersucht die Rolle der Spiele im Omanischen ELT-Lehrplan durch die Durchführung einer gründlichen Inhaltsanalyse des Grundbildungssystems Englischsprachige Lehrbücher über alle Sorten sowie die Suche nach den Einstellungen von Lehrern und Schülern von drei öffentlichen Schulen, die die drei Lehrzyklen im Bildungswesen darstellen System. Ein Inhaltsanalyseformular und ein Fragebogen wurden verwendet, um Daten zu sammeln. Die Ergebnisse zeigten, dass die Omani ELT Syllabi eine bescheidene Anzahl von kommunikativen Spielen über die Noten, die Mehrheit von ihnen konzentrieren sich auf das Unterrichten von Vokabeln mit einem sehr schüchternen Fokus auf die Sprachkenntnisse befürwortet. Darüber hinaus haben die Studierenden sehr positive Einstellungen über die Rolle der Spiele bei der Verbesserung ihrer Sprache, während Lehrer haben mäßig positive Einstellungen über ihre Rolle.

Schlüsselwörter: sprachlernspiele, einstellungen der lernenden, einstellung der lernenden, interaktives lernen

\section{Malaysian Abstract \\ Bermain dengan Bahasa: Penyiasat Peranan Komunikasi Permainan dalam Sistem Pengajaran Bahasa Arab}

Permainan pembelajaran Bahasa menggabungkan beberapa elemen linguistik, psikologi dan sosial yang telah didapati mempunyai kelebihan yang besar dan kuat memberi kesan pembelajaran pengajaran bahasa. Ia dimasukkan ke dalam kurikulum bahasa untuk menggalakkan 
pembelajaran interaktif yang menarik. Kajian ini menyiasat peranan permainan dalam sukatan pelajaran Oman ELT melalui analisis kandungan meneliti buku-buku teks bahasa Sistem Pendidikan Asas Bahasa Inggeris di semua gred serta mencari sikap guru dan pelajar daripada tiga sekolah-sekolah awam yang mewakili tiga sistem kitaran pengajaran dalam pendidikan. Satu bentuk analisis kandungan dan soal selidik telah digunakan untuk mengumpul data. Hasil kajian menunjukkan bahawa Omani ELT sukatan pelajaran meluluskan sejumlah kecil permainan komunikatif seluruh gred, majoriti yang memberi tumpuan kepada perbendaharaan kata pengajaran dengan memberi tumpuan sangat takut kepada kemahiran bahasa. Selain itu, pelajar mempunyai sikap yang sangat positif tentang peranan permainan dalam meningkatkan bahasa mereka manakala guru-guru mempunyai sikap yang sederhana positif tentang peranan mereka.

Kata Kunci: permainan pembelajaran bahasa, sikap pelajar, sikap guru, pembelajaran interaktif

\section{Russian Abstract \\ Языковые Игры: Исследование Роли Коммуникативных Игр в Системе Обучения Арабскому Языку}

Языковые Языковые обучающие игры сочетают в себе ряд лингвистических, психологических и социальных элементов, которые, как было установлено, обладают значительными преимуществами и влияют на изучение языка и его преподавание. Они включены в учебные планы для организации интерактивного обучения. В этом исследовании распознается роль игр в учебном плане ELT в Омане посредством проведения тщательного контентного анализа учебников английского языка базового образования по всем классам, а также отношения учителей и учащихся трех государственных школ, представляющих три учебных цикла в образовательной системе. Для сбора данных использовался анализ содержания и разрабатывались анкеты (вопросники). Результаты показали, что оманские программы ELT одобрили коммуникативные игры между классами, большинство из которых сосредоточено на обучение лексике со слабыми языковыми навыками. Кроме того, студенты очень позитивно относятся к роли игр, направленных на улучшение своего языка, тогда как учителя позитивно относятся к своей роли.

Ключевые Слова: языковые игры, отношение учителей, отношения учащихся, интерактивное обучение 